\title{
13
}

\section{Financing aged care: The role of housing wealth and intergenerational relationships}

\section{Rachel Ong}

The financing of aged care is in many ways the new frontier of policy response to population ageing. Over the next 40 years, the group that dominates demand for aged care - the 'old-old' - will increase more than any other. For example, the number of people aged over 85 is expected to quadruple. It is estimated that Australian Government aged-care expenditure will nearly double from 0.9 per cent to 1.7 per cent of GDP over the next 40 years (Commonwealth of Australia 2015).

Given the population and expenditure projections above, there exists an urgent need for establishing a sustainable system that offers adequate funding for aged residential and community care without crippling the fiscal budget. However, conflicting views persist in regard to the kinds of financing strategies that should be deployed. Successful execution of proposed solutions for financing aged care are typically hampered by conflicting ethical and operational issues that afflict co-existing and future generations. A major policy conundrum concerns the question of intergenerational equity, namely preserving the elderly's access to adequate funding for aged-care services without encumbering younger generations in their lifetime economic prospects. 
If funding for the needs of the aged are continually financed through government borrowing, and long-term budget deficits are therefore tolerated to support the care (and other) needs of a rapidly expanding group of elderly Australians, servicing and repayment of this fiscal debt will inevitably be borne by current and future generations of taxpayers.

This chapter considers the option of enabling older Australian home owners to draw on their housing assets to make a greater contribution to the funding of their personal aged-care needs. Specifically, the chapter explores the pros and cons of such a financing strategy within an intergenerational context.

\section{The intergenerational housing policy debate}

The changes in the demographic landscape introduced by growing longevity, and the fiscal concerns they raise, have been long anticipated in the policy sector. The need for positioning public policy formulation within an intergenerational context has been recognised by government, an obvious indication being the commitment to publication of the five-yearly Intergenerational Reports by both the current federal government and its predecessors.

However, the policy debate has taken on a new overtone in recent years. Traditionally, the elderly have been perceived as a universally resource-poor group in need of access to publicly funded care and support services. This emphasis has changed dramatically in recent years. It is increasingly recognised that many Australian ageing boomers have reaped significant windfall gains from soaring house prices from the mid-1990s to the mid-2000s. Between 1995 and 2005, real house prices in Australia climbed by around 80 per cent, outstripping the growth in real house prices in several other OECD countries that also experienced housing market booms, such as Canada and the United States (Girouard et al. 2006). Home owners also suffered less diminution of their housing wealth during the 2008 global financial crisis (GFC) than many of their counterparts overseas. House price index data from the Australian Bureau of Statistics show that while there was a very slight dip in the weighted average index 
for all capital cities during 2008 and the first half of 2009, the housing market quickly recovered such that the house price index was higher than pre-GFC levels again by late 2009 .

In general, baby boomers have enjoyed favourable conditions during their prime working years, which have provided a significant boost to their capacity to accumulate wealth. These conditions are illustrated in Figure 1 below, where the timing of higher education funding reforms, changes in labour and housing market conditions, and the introduction of the superannuation guarantee are related to the lifecourse of a median baby boomer. As the Australian Bureau of Statistics (2012) defines baby boomers as individuals born between 1946 and 1966, a median boomer is defined as someone who was born during the median year of this period (i.e. 1956).

As depicted in Figure 1, the Australian Government abolished tuition fees in the higher education sector in 1974 (Jackson 2003). The median boomer would have just turned 18 years old in 1974. S/he would therefore have been commencing higher education when the abolition was implemented. It would be another 15 years before the Higher Education Contribution Scheme (HECS) was introduced in 1989, and yet another eight years before the HECS contribution rate was raised for new students and lower HECS repayment thresholds applied in 1997 (Jackson 2003). Hence, most boomers born around and after 1956 would have enjoyed access to subsidised education that allowed them to build their human capital at a relatively low financial cost.

The years spanning the 80s, 90s and the new millennium also offered favourable labour market conditions for baby boomers during their prime working years. Broadly speaking, stable labour markets prevailed during this period. Unemployment rates generally hovered below 7 per cent, with the exception of the early 1980s and early 1990s when they peaked at above 10 per cent. However, these labour market slumps were short-lived in comparison with otherwise extended periods of high employment coinciding with healthy national economic conditions. Efforts at personal wealth accumulation were of course further boosted by the introduction of the Superannuation Guarantee in 1992, when a 'median' boomer would have been 36 years old. The introduction of the Superannuation Guarantee marked the start of a minimum level of mandated employer contributions to 
employees' superannuation. When introduced, it covered 80 per cent of employees; by 1999, this coverage had extended to 91 per cent (Australian Taxation Office 2011).

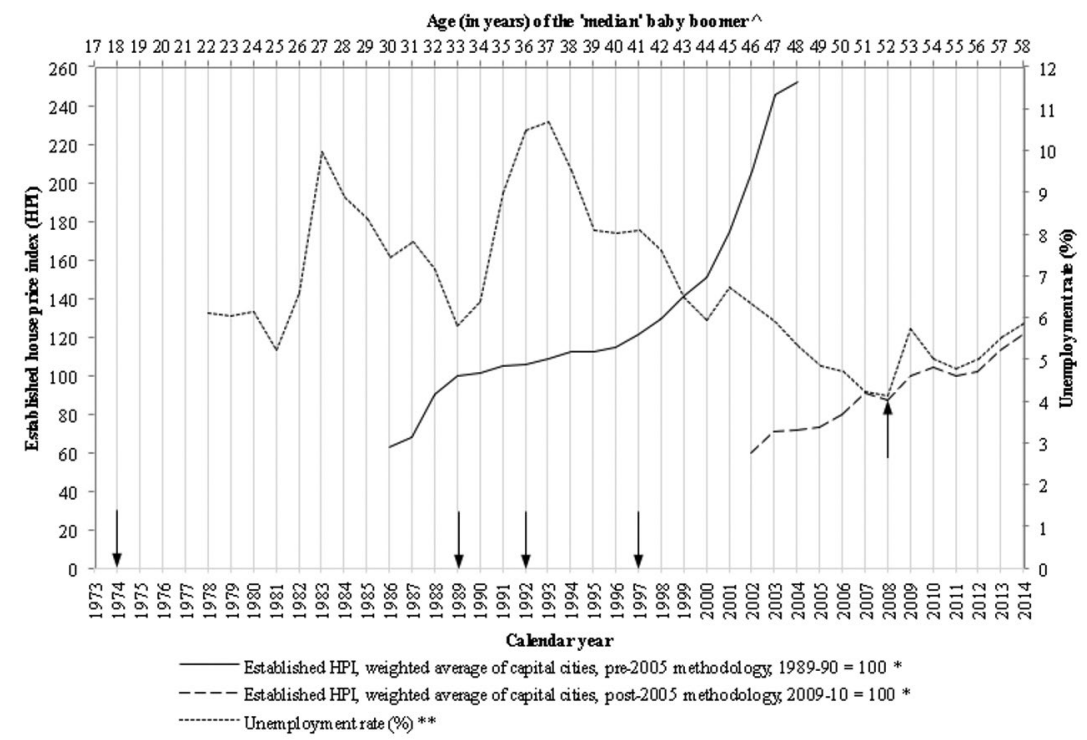

Figure 1. Higher education policies and labour and housing market conditions during the 1970s, 1980s, 1990s and new millennium

Source: Jackson (2003), Australian Bureau of Statistics (2012, 2015b, 2015c).

$\wedge$ The term baby boomers refers to the cohort born between 1946 and 1966 (Australian Bureau of Statistics 2012). A 'median' baby boomer is defined as an individual born in the median year of this period, that is, 1956.

* Established house price indexes (HPIs) are available from the Australian Bureau of Statistics from 1986. The HPls reported in this graph are taken from December of each year. In 2005, the Australian Bureau of Statistics changed its HPI methodology. Hence, the pre- and post-2005 trends are not directly comparable. However, they remain insightful with respect to highlighting peaks, troughs and exceptional trends.

** Unemployment rates are available from the Australian Bureau of Statistics from 1978 onwards. The rates reported in this graph are drawn from June of each year.

Housing market conditions played a momentous role in boosting the housing wealth of baby boomers who had owned a home by the mid1990s. House prices soared exponentially from the mid-1990s to the early 2000s, adding tremendously to the housing asset base of home owners in those years. As shown in Figure 1, the house price index shot up from 112 to 245 between 1995 and 2003, a spike of nearly 
120 per cent over an eight-year period. The decline in house prices during the GFC was reflected in just a slight dip in the house price index in 2008, followed by a quick rebound in 2009 .

Various studies agree that the favourable economic circumstances that prevailed during baby boomers' wealth accumulation years are unlikely to occur again during the wealth accumulation years of subsequent generations (Olsberg and Winters 2005; Forrest and Izuhara 2009). Housing affordability has been declining over the longrun so that those who were not fortunate enough to have purchased their homes by the time the housing market boom of the mid-1990s ended have found it increasingly difficult to access home ownership. Indeed, the median dwelling price to income multiple rose from approximately four to nearly seven between the mid-1990s and the early 2000s (Fox and Finlay 2012).

Young adults are also currently forging careers within a more precarious labour market environment than baby boomers did. Beer and Faulkner (2009) note that insecure and short-term forms of employment are particularly pronounced among younger people and therefore threaten their chances of attaining first home ownership status. Furthermore, these forms of employment are incompatible with the long-term financial commitment necessary for meeting home loan repayments. Hence, those fortunate enough to break into the home ownership market may find it increasingly difficult to meet mortgage repayments given their income levels after becoming home owners. Indeed, estimates from the Australian Bureau of Statistics' Surveys of Income and Housing (SIH) show that among young home owners aged 25-34 years owing a mortgage debt, the average mortgage debt to income ratio was under 110 per cent back in 1990. However, this ratio had escalated to over 210 per cent for this age group by 2011 .

In the post-GFC era, youth unemployment is once again on the rise (Australian Bureau of Statistics 2015b). Furthermore, young people on the verge of entry into higher education are facing a distinct possibility of having to pay unsubsidised tuition fees, should the tertiary sector deregulation reforms proposed in the 2014 Budget (see Hockey 2014) be implemented in some form in the near future. It is therefore conceivable that by virtue of the timing of their birth, younger generations will have fewer opportunities to accumulate economic resources than the average boomer did. 


\section{A housing asset-based system for financing aged care}

The developments described above have led to a shift in policy perspective that increasingly recognises that some older Australians are in fact well positioned to tap into their personal resources to meet their care and support needs in old age. In particular, many baby boomers currently hold significant levels of housing wealth, so in various countries with high levels of home ownership, the policy direction in relation to funding both residential and community aged care has seen incremental shifts towards encouraging personal responsibility through the use of housing assets.

Government agencies in some countries have explicitly recommended the drawdown of housing equity to help pay for aged-care needs. The Productivity Commission's inquiry into the aged-care sector argues that 'many older Australians with low income have substantial wealth, which gives them the capacity to meet their lifetime accommodation costs and to make a modest contribution to the costs of their care' (Productivity Commission 2011: xxvi). Specifically, the Productivity Commission (2011: 108) has recommended a government-backed Aged Care Equity Release scheme that will allow an older home owner to use 'a maximum amount, say 40 to 60 per cent', of their housing equity to help finance their accommodation and care costs, with no or limited repayments until the ownership of the home is transferred to another individual. A similar shift has been observed in the UK, where the Dilnot Commission Report (2011) has emphasised personal responsibility as the starting point for meeting the costs of care in old age, which can be paid from income, savings, housing assets or financial products that allow equity release. Furthermore, in Australia, recently announced aged-care financing reforms have introduced national means testing and user charges for community and residential care which take into account income and assets including the primary home (Australian Department of Social Services 2014).

In light of these developments, the rest of this chapter examines the pros and cons of positioning housing wealth as an asset base for financing aged care. Specifically, the chapter explores this proposed policy direction vis-à-vis consequences for intergenerational relationships. 


\section{Arguments for using housing wealth to finance aged care}

\section{Preferential tax treatment of home ownership}

The majority of Australia's housing subsidies are provided to encourage home ownership. Housing consumers have traditionally received various forms of direct and indirect subsidies from governments to assist with home purchase and with meeting housing cost burdens once they become owners. Home buyers received non-means-tested direct purchase assistance in the form of the First Home Owners Grant, as well as stamp duty concessions. Existing home owners receive preferential treatment of the family home within both the tax and income support systems. Specifically, home owners have typically enjoyed non-taxation of imputed rent, and the exemption of the family home from a range of taxes include the Goods and Services, capital gains tax and land tax. The family home has also traditionally been exempt from the assets test that determine eligibility for incomesupport payments such as the age pension.

In comparison to home owners, the range of subsidies available to renters is much narrower and mainly come in the form of Commonwealth Rent Assistance and public housing rebated rents that are tightly targeted at those on low incomes. The amount of housing subsidies received by owners far outweighs the amount received by renters. In their report on housing taxes and transfers commissioned by the Australia's Future Tax System Review, Wood et al. (2010) estimated the average housing subsidy received by private renters in 2006 at $\$ 901$ (1.1 per cent of income), while home owners received an average of $\$ 2,201$ (2.5 per cent of income).

Successive decades of preferential tax treatments and concessionary assets tests that exclude the primary home from means tests have promoted extensive accumulation of wealth in housing assets by home owners. Some of these favourable tax advantages would no doubt have been capitalised into house prices. Together with historically low interest rate settings, these preferential tax treatments for home owners have pushed house prices to ever higher levels in recent decades, exacerbating barriers to home purchase by the non-home owning part of the population. Furthermore, tax expenditures and 
means test concessions that apply to home owners only are in fact subsidised by non-home owners. Hence, concerns of inequitable treatment of owners versus renters within the current tax-transfer system could be mitigated if some of the housing wealth accumulated by home owners with the support of preferential policy parameters were diverted to fund their care needs in old age.

\section{A growing intergenerational housing wealth gap}

An important society-wide consequence of the developments described thus far is the growing gap between generations with respect to housing wealth. Table 1 compares the housing wealth of two age cohorts. Ironically, what appear to have been large economic gains for baby boomer owner-occupiers have placed the 'great Australian dream' of attaining home ownership increasingly out of the reach of younger generations, now commonly dubbed 'Generation Rent' (McKee 2012).

This growing intergenerational housing wealth gap is documented in Table 1, which compares the housing wealth of those aged 45-64 and 25-44. Households aged 45-64 in 2011 broadly comprise baby boomers, while those aged 25-44 in 2011 are drawn from Generations $X$ and Y (Australian Bureau of Statistics 2012). Table 1 shows that in 2011, the mean housing wealth of those aged 45-64 years was 2.5 times the mean housing wealth of those aged 25-44. In absolute gap terms, the mean housing wealth of those aged 45-64 years in 2011 was over \$230,000 higher than those aged 25-34 years. As such, in 2011 the average baby boomer held almost half the population's share of housing wealth, while the 25-44 age group held a comparatively smaller share of 18 per cent. This resulted in an intergenerational gap of 31 percentage points between the two age cohorts in 2011.

Table 1 further explores the housing wealth levels of the two age groups about 20 years prior. Back in 1990, the gap in mean housing wealth between the two age groups was much narrower at $\$ 92,000$ (compared to $\$ 230,000$ in 2011). In terms of shares, those aged 45-64 years in 1990 owned around 42 per cent of the population's housing wealth compared to a 34 per cent ownership by those aged 25-44 years. Once again, the gap between the two age groups was much smaller in 1990, at eight percentage points (compared to 31 percentage points in 2011). 
Table 1: Gaps in housing wealth between those aged 45-64 and 25-44 years old, 1990 and 2011*

\begin{tabular}{|c|c|c|}
\hline & 1990 & 2011 \\
\hline \multicolumn{3}{|l|}{ Mean housing wealth } \\
\hline 25-44 years & $\$ 138,302$ & $\$ 149,451$ \\
\hline 45-64 years & $\$ 229,849$ & $\$ 379,739$ \\
\hline Gap between age groups & $\$ 91,547$ & $\$ 230,288$ \\
\hline \multicolumn{3}{|c|}{ Share of population's housing wealth } \\
\hline 25-44 years & $34 \%$ & $18 \%$ \\
\hline 45-64 years & $42 \%$ & $49 \%$ \\
\hline Gap between age groups & $8 \%$ points & $31 \%$ points \\
\hline
\end{tabular}

Source: Australian Bureau of Statistics Survey of Income and Housing 1990 and 2011.

* Dollar values are reported in 2011 price levels. According to the Australian Bureau of Statistics (2015a), the Consumer Price Index (CPI) was 57.5 in 1990 and 99.3 in 2011. Hence, all 1990 values have been inflated by an inflator of 1.729 (or 99.3/57.5).

Given the estimates reported in Table 1, it is arguably reasonable on equity grounds to expect home-owning boomers to draw on some of their dividends gained (at least partially) from preferential policy treatment of the family home and the housing market boom of the late 1990s to early 2000s to finance their care needs in old age, thus relieving some of the fiscal burden that segments of the population with comparatively lower levels of housing equity would otherwise have to carry.

\section{Intragenerational concerns within older cohorts}

While intergenerational housing wealth inequities are a cause for concern, another equally worrying phenomenon is that of intragenerational housing wealth gaps within older cohorts. Thus far, the discussion has revolved around the 'average' or 'median' baby boomer, who is depicted as a home-owning individual who has made significant gains from the favourable economic conditions illustrated in Figure 1 and longstanding preferential tax treatment of owner occupation. However, in reality, significant intra-cohort variations exist among the older segment of the population. Specifically, there are some older persons who cannot benefit from the housing wealth possessed by the typical boomer owner occupier. These are the minority of older persons who do not own housing assets and therefore have comparatively much lower levels of wealth than their home-owning peers. 
Estimates from the SIH show that in 2011, approximately one-quarter of persons aged 45-64 years did not own the dwelling they lived in. Over the long-run, the non-home-owning population in this age group has grown in proportionate terms. In 1990, non-home owners made up a comparatively lower one-fifth of the population aged 45-64 years.

These older non-home owners principally comprise lifetime renters who have not had opportunities to accumulate housing wealth or those unfortunate enough to lose home ownership through adverse life events such as divorce or ill-health. Ong et al. (2014) find that among persons aged 45 years and over during the decade 2001-10, around 742,000 spells of home ownership ended with a move out of owner occupation during the decade. The study also found that those who lose home ownership as a result of some unfavourable biographical event such as marital breakdown, bereavement or long-term health conditions are at increased risk of needing publicly funded rental housing assistance in older age.

Older Australian renters who do not own housing assets will be particularly adversely affected if governments are forced to cut spending on housing assistance, income support or care and support services to address long-term budget deficits. Colic-Peisker et al. (2014) highlighted the detrimental effect that asset poverty has on older Australians' ontological security and found that some older renters have had to severely restrict non-housing consumption in order to cope with meeting housing costs post-retirement. Hence, fiscal savings derived from home owners' use of personal assets to finance their aged care would ease the burden on taxpayer funding of care and support for the elderly who do not have access to housing wealth.

\section{Mitigating intergenerational transmission of advantage}

Bequest motives are often cited as an argument against the drawdown of equity. However, intergenerational transfers of assets through bequests or inter-vivos transfers may entrench and in some cases exacerbate existing wealth inequality (Angel and Mudrazija 2011; Searle and McCollum 2014). There is a consensus in the international literature that those who come from affluent socioeconomic backgrounds are most likely to receive substantial intergenerational transfers (Kohli 1999; Rowlingson and McKay 2005). Indeed, estimates from the nationally representative Household, Income and Labour 
Dynamics in Australia (HILDA) Survey confirm exactly this pattern. The data shows that 26 per cent of bequest recipients in 2011 already resided in an advantaged area in the year prior to receiving the bequest as compared to 20 per cent of those who did not receive bequests in 2011. Furthermore, 72 per cent of bequest recipients were individuals who could themselves easily raise emergency funds compared to 60 per cent of non-recipients. Bequest recipients also possess more well-developed human capital than non-recipients; 77 per cent of bequest recipients in 2011 were already employed in the year prior to receiving the bequest compared to 69 per cent of non-recipients, and 36 per cent of bequest recipients in 2011 had a university qualification compared to 24 per cent of non-recipients. Hence, encouraging equity release by those who can afford it to provide for their own care needs might in fact go some way towards combating the entrenchment of wealth inequality associated with intergenerational transmission of advantage.

In addition, bequests are typically received later in the life-course due to longer life expectancies among aged parents. Thus, the timing of intergenerational wealth transfers through bequests is often not early enough in the life-course to assist young adults at a time when they are purchasing their first home. The 2011 HILDA Survey data shows that the median age at which Australians receive intergenerational transfers through bequests is 49 years old, by which time over threequarters of bequest recipients have already bought their own homes.

At a macro level, the rationale for encouraging a shift to the use of personal housing assets to finance aged care is therefore obvious. Such a policy reform has the potential to promote intergenerational equity by reducing the fiscal burden on younger cohorts who presently have lower chances of attaining home ownership than similarly aged cohorts did in past decades and (at least partially) addressing the perpetuation of wealth inequality associated with intergenerational transmission of advantage to young cohorts from affluent backgrounds. The reform would also weaken the prospect of government-funding cuts to support systems in core areas such as housing, income and care that would have more acute consequences for older Australians with low asset levels than those who possess housing wealth.

1 This is defined as the top two deciles of the Australian Bureau of Statistics' index of relative socioeconomic advantage/disadvantage. 


\section{Arguments against using housing wealth to finance aged care}

\section{Threats to intergenerational reciprocity}

Despite some obvious benefits in adopting a housing asset-based aged-care financing strategy, decisions about asset use and economic provisioning in old age are often complex, and plagued with difficulties. First and foremost is the emotional attachment that owner occupiers and their children have towards the family home. The housing assets of elderly parents are often viewed not just as their personal resources, but as the future inheritance of their children. Equity release by elderly parents might understandably be unpopular if they have the potential to fracture family relationships where adult children had expected to inherit their parents' assets. Indeed, Ong et al. (2013) found that children who are expecting to benefit from inheriting their elderly parents' homes often express concerns about the use of debt finance (e.g. reverse mortgages) by their parents to draw down on the wealth stored in the family home and may get actively involved in decisions by elderly parents with regards to the use of their housing assets. Hence, under a housing asset-based aged-care financing system, some elderly persons will likely face a dilemma at the family level in relation to balancing their desire to transfer as much of their housing assets as possible to their adult children against meeting their personal need for adequate care in old age.

The intra-familial scenario described above is but one example of the complexities that govern the links between intergenerational wealth transfers and intergenerational reciprocity in care. Previous studies have cautioned that a lack of intergenerational asset accumulation may weaken traditional ties between the old and the young, resulting in resentment and growing unwillingness among working-age adults to care for the elderly (see, for example, Hudson 1999). Angel and Mudrazija (2011: 170) note that:

it would be naïve to think that human motivations are solely altruistic or that we possess an unlimited capacity for self-sacrifice ... a system in which the accumulation of assets ties one generation to the next is one in which bonds of generational reciprocity and affection are maximised. Conversely, a system in which the material ties between children and parents are weak faces the risk of turning the young and the old into strangers. 
Even if adult children are supportive of their parents releasing some housing equity for funding personal aged-care needs, financial risks and impediments exist. These financial risks and impediments, as described below, can act to significantly reduce housing assets below levels that are intended for bequest purposes unless adequate safeguards are put in place to counter their impacts on equity levels in old age.

\section{Financial risks and barriers}

Any financing strategy that is housing asset-based is predicated on the assumption that investment in 'bricks and mortar' will yield significant returns as house prices continue to rise over the long-term. To date, the Australian housing market has proven to be remarkably resilient even throughout the GFC. However, recent economic events worldwide have undeniably highlighted some risks of relying on housing as a vehicle for supporting retirement needs. Housing asset values are also thought to be more vulnerable to changing consumer sentiments because of greater difficulty in determining true asset values (Shiller 2005; Baker and Wurgler 2007). Furthermore, housing assets are a unique financial investment in that the risks associated with future house price movements cannot be hedged (Shiller 2003). House price volatility can expose home owners who engage in equity release to undesirable levels of house price risks. These risks in turn have the potential to significantly reduce the value of housing assets unless government policy establishes a floor in retained levels of equity.

Another financial concern exists in the form of repayment risk, for those who use equity release products to withdraw housing equity. Baby boomers currently aged 45-64 years are now exhibiting higher degrees of mortgage indebtedness compared to similarly aged cohorts in the past. Long-run trends from the SIH show that the proportion of home owners with a mortgage debt has increased in every age group between 1990 and 2011, but this rise in indebtedness has been the steepest (around 30 percentage points) amongst home owners aged 45-64 years. The incidence of mortgage indebtedness jumped from 38 per cent to 70 per cent among those aged $45-54$ years, and from 15 per cent to 44 per cent among those aged 55-64 years between 1990 and 2011. These statistics are complemented by evidence from 
the 2001 and 2010 HILDA Survey showing that the proportion of boomer owners, who engaged in equity release by increasing debt against their primary home, rose over the decade from 18 per cent to 24 per cent among those aged 45-54 years and 8 per cent to 16 per cent among those aged 55-64 years. These higher levels of mortgage debt can leave baby boomers more precariously positioned financially, with only a limited number of years left in the workforce to pay off their mortgage debt. These risks are augmented should adverse life events such as divorce, unemployment or ill health befall boomers who have not yet paid off their mortgage debt.

\section{$\%$ of owners with a mortgage debt}

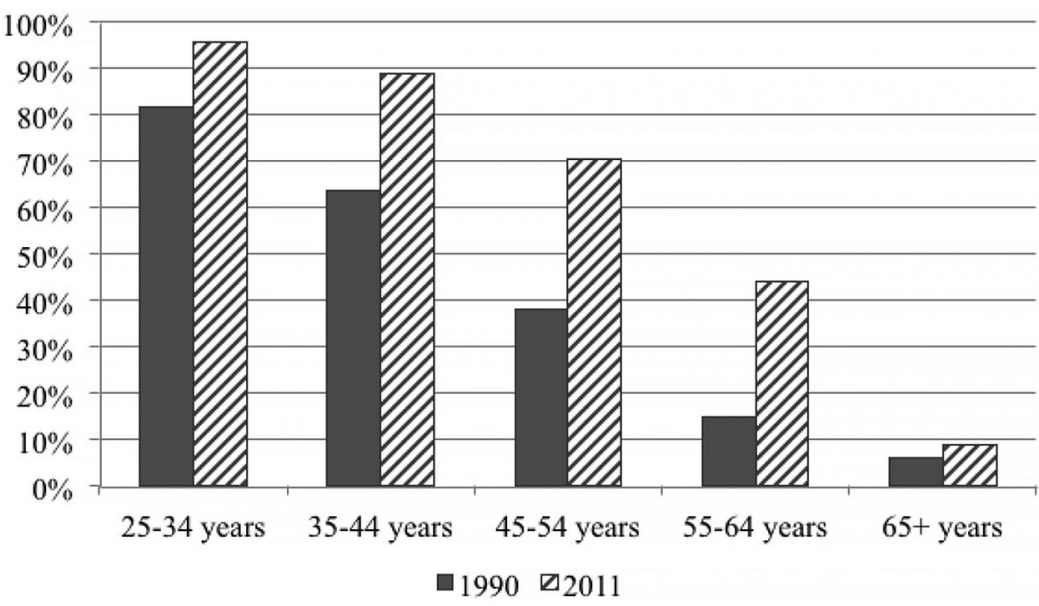

Figure 2. Incidence of mortgage indebtedness amongst home owners, 1990 and 2011

Source: Authors own calculations from the confidentialised unit record files of the Australian Bureau of Statistics Survey of Income and Housing 1990 and 2011.

Government could play an effective role in promoting the acceptance of equity release products for financing aged-care needs, by providing insurance against its downside risks. Indeed, there are several international developments that provide evidence on the merits of such government involvement, such as in the case of the Home Equity Conversion Mortgage (HECM) product in the United States. The HECM is federally insured and therefore the risk is transferred to the Federal Housing Administration, allowing eligible older home owners to release the equity stored in their home in a secure manner (Federal Housing Administration 2010). The HECM is typically 
considered a safe option for equity release in the United States, where it accounts for a dominant share of the equity release market (Alai et al. 2013). At the same time, Beal (2001) has pointed out that the development of an equity-release market that caters for the elderly is unlikely to be smooth where its development is not facilitated by the government. More recently, the Productivity Commission (2011: 106) makes a similar observation by noting that a 'government-backed ... equity release scheme may be more acceptable to some older people. The higher uptake of government-sponsored schemes, relative to private provider schemes, in the US suggests that the added security from government backing can help dispel nervousness about using the products.'

Releasing housing equity via the traditional sale method can mitigate some of the repayment risk concerns associated with the use of equity release products. However, transaction costs may deter home owners considering downsizing because they represent a significant upfront cost on their next purchase. Economists have long opposed the stamp duty because it is an inefficient tax that deters residential mobility and has adverse impacts on home purchase affordability. Indeed, Ong et al. (2013) found that during the period 2001-10, stamp duties ate into 8 to 10 per cent of the housing equity that home owners aged $45+$ released via downsizing.

In addition, Judd et al. (2014) identified some major housing market difficulties associated with downsizing in later life. These include a lack of suitable housing types and locations, as well as concerns over the affordability of housing. There seems to be a general consensus that older Australians increasingly wish to age in place for as long as possible. This often involves emotional attachment not just to one's home, to one's neighbourhood. Hence, those who are willing to downsize often express a strong desire to do so within the same area so as to maintain links with their community in old age (Ong et al. 2013; Judd et al. 2014). However, home owners often face difficulties with finding an affordable property within the same neighbourhood to downsize into. Tackling inefficient taxes such as the stamp duty through policy reform would go some way towards alleviating the emotional impact and practical difficulties that often accompany downsizing. For instance, Wood et al. (2012a, 2012b) has provided empirical evidence that the abolition of stamp duty and its replacement 
by a broad-based land tax would promote residential mobility by reducing upfront cost barriers and mitigate affordability concerns because a broad-based land tax burden will be capitalised into lower land prices. Such a reform has the potential to tackle both mobility and affordability concerns that are impediments to downsizing.

\section{Concluding comments}

It is unsurprising that governments are increasingly looking towards those with sufficient assets in old age to contribute to their cost of being supported and cared for in old age. The pressure on individuals to assume greater responsibility for their aged-care needs will only intensify in the coming years, as governments strive to manage the fiscal challenges of accelerated rates of population ageing, especially among the oldest-old.

There are some strong intergenerational equity arguments for instituting housing wealth as a pillar of aged-care policy. If older home owners were enabled to draw on some of their housing wealth to contribute to the funding of their aged-care needs, it would no doubt relieve intergenerational equity concerns at a macro level. However, more research needs to be done to unearth and disentangle the potentially complex links between intergenerational asset accumulation and intergenerational reciprocity to avert the undesirable consequence of alienating the young from the old. Furthermore, much more work needs to done to devise equity release products that allow elderly home owners to draw down on their housing wealth in a secure manner that will leave them with an appropriate minimum level of equity. An in-depth assessment would be required of the multitude of risks (and associated solutions) at each stage of product development, including product design, regulatory framework, pricing, etc.

Policy support for family models of caring for aged parents may alleviate the need for releasing equity to access formal aged-care services and thus avoid some of the more intricate difficulties associated with equity and equality discussed in this chapter. Informal housing and care arrangements often provide opportunities for two-way intergenerational support. For instance, elderly grandparents who provided childcare for grandchildren in earlier years may benefit from family reciprocity in the form of aged care from their adult children 
when frailty sets in. The leakage of housing wealth outside the family, which typically occurs through the use of equity to pay for formal care services, is averted when family members enter into informal housing and care arrangements within a multigenerational household context. However, informal care solutions are not without its challenges, and will have to be crafted thoughtfully with sufficient safeguards for the wellbeing of all family members.

At a macro level, there also exists a long-standing conflict between the provision of informal care to family members and participation in the paid labour market. For instance, international studies have consistently found that working-age carers who provide informal care for ill, frail or disabled family members typically have depressed levels of labour force participation compared to those who do not carry these care responsibilities (see for instance, Austen and Ong 2010; Carmichael et al. 2008). The issue is particularly pronounced among women, who are over-represented among informal carers. Here, policies will need to carefully navigate the tension between encouraging household production of aged care services and lifting economic productivity vis-à-vis greater labour force participation, both of which are necessary policy ambitions to address fiscal challenges in an era of population ageing.

\section{Acknowledgements}

This chapter uses unit record data from the Household, Income and Labour Dynamics in Australia (HILDA) Survey. The HILDA Project was initiated and funded by the Australian Government Department of Social Services and is managed by the Melbourne Institute of Applied Economic and Social Research. The author would like to thank Mike Woods for offering helpful suggestions and comments on the chapter. The findings and views reported in this chapter, however, are those of the author and should not be attributed to any other individual or organisation. 


\section{References}

Alai Daniel, Chen Hua, Cho Daniel, Hanewald Katja and Sherris Michael (2013). Developing Equity Release Markets: Risk Analysis for Reverse Mortgages and Home Reversions, Working Paper No. 2013/01, ARC Centre for Excellence in Population Ageing Research.

Angel Jacqueline and Mudrazija Stipica (2011). Aging, inheritance, and gift-giving. In RH Binstock and LK George (Eds) Handbook of Aging and the Social Sciences (7th edition). San Diego: Academic Press, pp. 163-173.

Austen S and Ong R (2010). The employment transitions of mid-life women: Health and care effects. Ageing and Society, 30(2): 207-227.

Australian Bureau of Statistics (2012). Reflecting a Nation: Stories from the 2011 Census, Canberra: Australian Bureau of Statistics.

Australian Bureau of Statistics (2015a). Consumer Price Index, Australia, Time Series Workbook, Cat. No. 6401.0, Canberra: Australian Bureau of Statistics.

Australian Bureau of Statistics (2015b). Labour Force, Australia, Time Series Workbook, Cat. No. 6202.0, Canberra: Australian Bureau of Statistics.

Australian Bureau of Statistics (2015c). Residential Property Price Indexes: Eight Capital Cities, Time Series Workbook, Cat. No. 6416.0, Canberra: Australian Bureau of Statistics.

Australian Department of Social Services (2014). Aged Care Means Test Assessments. www.humanservices.gov.au/customer/services/ aged-care-means-test-assessments.

Australian Taxation Office (2011). 20 Years of Superannuation Guarantee, www.ato.gov.au/Media-centre/Commissioners-onlineupdates/20-years-of-super-guarantee/.

Baker Malcolm and Wurgler Jeffrey (2007). Investor sentiment in the stock market. Journal of Economic Perspectives, 21(2): 129-151.

Beal Diana (2001). Home equity conversion in Australia-issues, impediments and Possible solutions, Economic Papers, 20(4): 55-68. 
Beer Andrew and Faulkner Deborah (2009). 21st Century Housing Careers and Australia's Housing Future, Final Report No. 128, Melbourne: Australian Housing and Urban Research Institute.

Carmichael Fiona, Hulme Claire, Sheppard Sally and Connell Gemma (2008). Work-life imbalance: Informal care and paid employment in the UK. Feminist Economics, 14(2): 3-35.

Colic-Peisker Val, Ong Rachel and Wood Gavin (2014, published online). Asset poverty, precarious housing and ontological security in older age: An Australian case study. International Journal of Housing Policy. doi: 10.1080/14616718.2014.984827.

Commonwealth of Australia (2015). 2015 Intergenerational Report: Australia in 2055. Canberra: Department of Treasury. www. treasury.gov.au/PublicationsAndMedia/Publications/2015/2015Intergenerational-Report

Daley John and Wood Danielle (2014). The Wealth of Generations, Melbourne: GRATTAN Institute. grattan.edu.au/report/thewealthof-generations/.

Dilnot Andrew, Warner Norman and Williams Jo (2011). Fairer Care Funding: The Report of the Commission on Funding of Care and Support. London: UK Commission on Funding of Care and Support, Final Report. www.thirdsectorsolutions.net/index.php?id=75.

Federal Housing Administration (2010). Consumer Fact Sheet for Home Equity Conversion Mortgages (HECM), 1 November. portal.hud. gov/hudportal/documents/huddoc?id=DOC13006.pdf.

Forrest Ray and Izuhara Misa (2009). Exploring the demographic location of housing wealth in East Asia. Journal of Asian Public Policy, 2(2): 209-221.

Fox Ryan and Finlay Richard (2012). Dwelling prices and household income. Bulletin, December quarter: 13-22.

Girouard Nathalie, Kennedy Mike, van den Noord Paul and André Christophe (2006). Recent House Price Developments: The Role of Fundamentals, OECD Economics Department Working Papers, No. 475, OECD Publishing. dx.doi.org/10.1787/864035447847. 
Hockey Joe (2014). Budget Speech 2014-15, 13 May, www.budget.gov. $\mathrm{au} / 2014-15 /$ content/speech/html/speech.htm.

Hudson Robert (1999). Conflict in today's aging politics: new population encounters old ideology. Social Service Review, 73: $358-379$.

Jackson K (2003). Higher Education Funding Policy, Parliament of Australia, www.aph.gov.au/About_Parliament/Parliamentary_ Departments/Parliamentary_Library/Publications_Archive/ archive/hefunding.

Judd Bruce, Liu Edgar, Easthope Hazel, Davy Laura and Bridge Catherine (2014). Downsizing Amongst Older Australians, Final Report No. 214, Australian Housing and Urban Research Institute, Melbourne.

Kohli Martin (1999). Private and public transfers between generations: linking the family and the state. European Societies, 1(1): 81-104.

McKee Kim (2012). Young people, homeownership and future welfare. Housing Studies, 27(6): 853-862.

Olsberg Diana and Winters Mark (2005). Ageing in Place: Intergenerational and Intrafamilial Housing Transfers and Shifts in Later Life, Final Report No. 88, Melbourne: Australian Housing and Urban Research Institute.

Ong Rachel, Jefferson Therese, Wood Gavin, Haffner Marietta and Austen Siobhan (2013). Housing Equity Withdrawal: Uses, Risks, and Barriers to Alternative Mechanisms in Later Life, Final Report No. 217, Melbourne: Australian Housing and Urban Research Institute.

Ong Rachel, Wood Gavin and Colic-Peisker Val (2014). Housing older Australians: Loss of homeownership and pathways into housing assistance. Urban Studies, published online. doi: 10.1177/0042098014550955.

Productivity Commission (2011). Caring for older Australians, Report No. 53, Final Inquiry Report, Canberra: Productivity Commission.

Rowlingson Karen and McKay Stephen (2005). Attitudes to Inheritance in Britain. York: Joseph Rowntree Foundation. 
Searle Beverley and McCollum David (2014). Property-based welfare and the search for generational equality. International Journal of Housing Policy, 14(4) 325-343. doi: 10.1080/14616718.2014.955334.

Shiller Robert (2003). The New Financial Order: Risk in the 21st Century. Princeton, New Jersey: Princeton University Press.

Shiller Robert (2005). Irrational Exuberance. Princeton, New Jersey: Princeton University Press.

Wood Gavin, Stewart Miranda and Ong Rachel (2010). Housing Taxation and Transfers, Final Report, Research Study for the Review of Australia's Future Tax System, taxreview.treasury.gov. $\mathrm{au} /$ content/html/commissioned_work/downloads/wood_stewart_ and_ong.pdf.

Wood Gavin, Ong Rachel and Winter Ian (2012a). Stamp duties, land tax and housing affordability: The case for reform. Australian Tax Forum, 27(2): 331-349.

Wood Gavin, Ong Rachel, Cigdem Melek and Taylor Elizabeth (2012b). The Spatial and Distributional Impacts of the Henry Review Recommendations on Stamp Duty and Land Tax, Final Report No. 182, Melbourne: Australian Housing and Urban Research Institute. 
This text is taken from Population Ageing and Australia's Future, edited by Hal Kendig, Peter McDonald and John Piggott, published 2016 by ANU Press, The Australian National University, Canberra, Australia. 